\title{
Two new species of Lachesilla in species groups riegeli and forcepeta (Psocodea, 'Psocoptera', Lachesillidae), from the state of Bahia, Brazil
}

\author{
Alfonso N. García Aldrete ${ }^{1} \&$ Alberto Moreira da Silva Neto ${ }^{2}$
}

\author{
${ }^{1}$ Departamento de Zoología, Instituto de Biología, Universidad Nacional Autónoma de México, Apartado Postal 70-153, 04510 México, D. F. \\ México. anga@ib.unam.mx \\ ${ }^{2}$ Programa de Pós-Graduação em Entomologia, Instituto Nacional de Pesquisas da Amazônia - INPA, CPEN - Campus II, Caixa postal 478, \\ 69090-001 Manaus-AM Brazil. bio.alberto@gmail.com
}

\begin{abstract}
Two new species of Lachesilla in species groups riegeli and forcepeta (Psocodea, 'Psocoptera', Lachesillidae), from the state of Bahia, Brazil.Two new species of Lachesilla from the Brazilian state of Bahia are here described and illustrated. Lachesilla cladoclaspers sp. nov., in species group riegeli, was collected in the Chapada Diamantina, Lachesilla nilopecanhensis sp. nov., in species group forcepeta, was collected in Nilo Peçanha, southern Bahia.
\end{abstract}

KEYWORDS. Insecta; Lachesillinae; neotropics; taxonomy.

Lachesilla is the most species-rich psocid genus. It presently includes 309 described species, in 19 species groups (personal unpublished information). One hundred thirteen species occur in South America, in 11 species groups. Species group riegeli (García Aldrete 1974; Mockford 1993) has two species represented in Brazil, Lachesilla matogrossensis García Aldrete, 1997 from the state of Mato Grosso, and Lachesilla paulista García Aldrete, 1982 from the state of São Paulo. Species group forcepeta (García Aldrete 1974; Mockford 1993) has 19 species represented in Brazil (Garcia Aldrete, 2000), with two of them present in the state of Bahia, Lachesilla bahiana García Aldrete, 2000 and Lachesilla convexa García Aldrete, 2000 (Garcia Aldrete \& Mockford 2009). We recently collected, in the state of Bahia, one undescribed species each in species groups riegeli and forcepeta. The purpose of this paper is to describe and illustrate those two species.

\section{MATERIAL AND METHODS}

One male and two females of the species in group riegeli, and one male of the species in group forcepeta were available for study. The three specimens were dissected in $80 \%$ ethanol, and their parts (head, right wings and legs and genitalia) were mounted on slides in Canada balsam. Standard measurements were taken on parts on the slides, utilizing a filar micrometer with measuring unit of 136 microns for wings, and 53 microns for other parts. Abbreviations of parts measured are as follows: FW, HW: lengths of right fore- and hind- wings; $F, T, t_{1}$ and $t_{2}$ : lengths of femur, tibia, and tarsomeres 1 and 2 of right hind leg; Mx4: length of fourth segment of right maxillary palpus; $\mathrm{ctt}_{1}$ : number of ctenidobothria on $t_{1} ; f_{1} \ldots f_{n}$ : lengths of flagellomeres $1 \ldots$ of right antenna; IO, D, d: respectively, minimum distance be- tween compound eyes, antero-posterior diameter, and transverse diameter of right compound eye, all in dorsal view of head; PO: $\mathrm{d} / \mathrm{D}$.

The types will be deposited in the Coleção Entomológica Prof. Johann Becker of the Museu de Zoologia da Universidade Estadual de Feira de Santana (MZUEFS), Feira de Santana, Bahia, Brazil.

\section{TAXONOMY}

Species of the genus Lachesilla Westwood, 1840 can be distinguished from other genera of Lachesillinae by the following characters: Ocelli present. In forewings Rs fork stem only slightly curved; vein Cu1a free from M. Phallosome with one apodeme or two separate apodemes; aedeagal arch absent, external parameres absent as such. Hypandrium usually bearing pair of lateral processes (claspers). Ovipositor valvulae: v3 usually rounded at apex, occasionally pointed but point never spinose (Mockford, 1993). For the diagnoses of the species group riegeli and forcepeta see Garcia Aldrete (1974) and Mockford (1993).

\section{Lachesilla cladoclaspers sp. nov.}

(Figs. 1-6)

Diagnosis. It is the only species in species group riegeli having the male claspers distally branched, the gonapophyses are relatively slender; it lacks short appendages on the ninth sternum; pointed distal pieces of phallosome completely fused to the base. Lachesilla cuna García Aldrete, 1982, from Panama, and L. paulista, from Argentina and Brazil, with claspers unbranched, have, as in L. cladoclaspers, one long, acuminate apophysis mesally in each clasper, directed outward. 


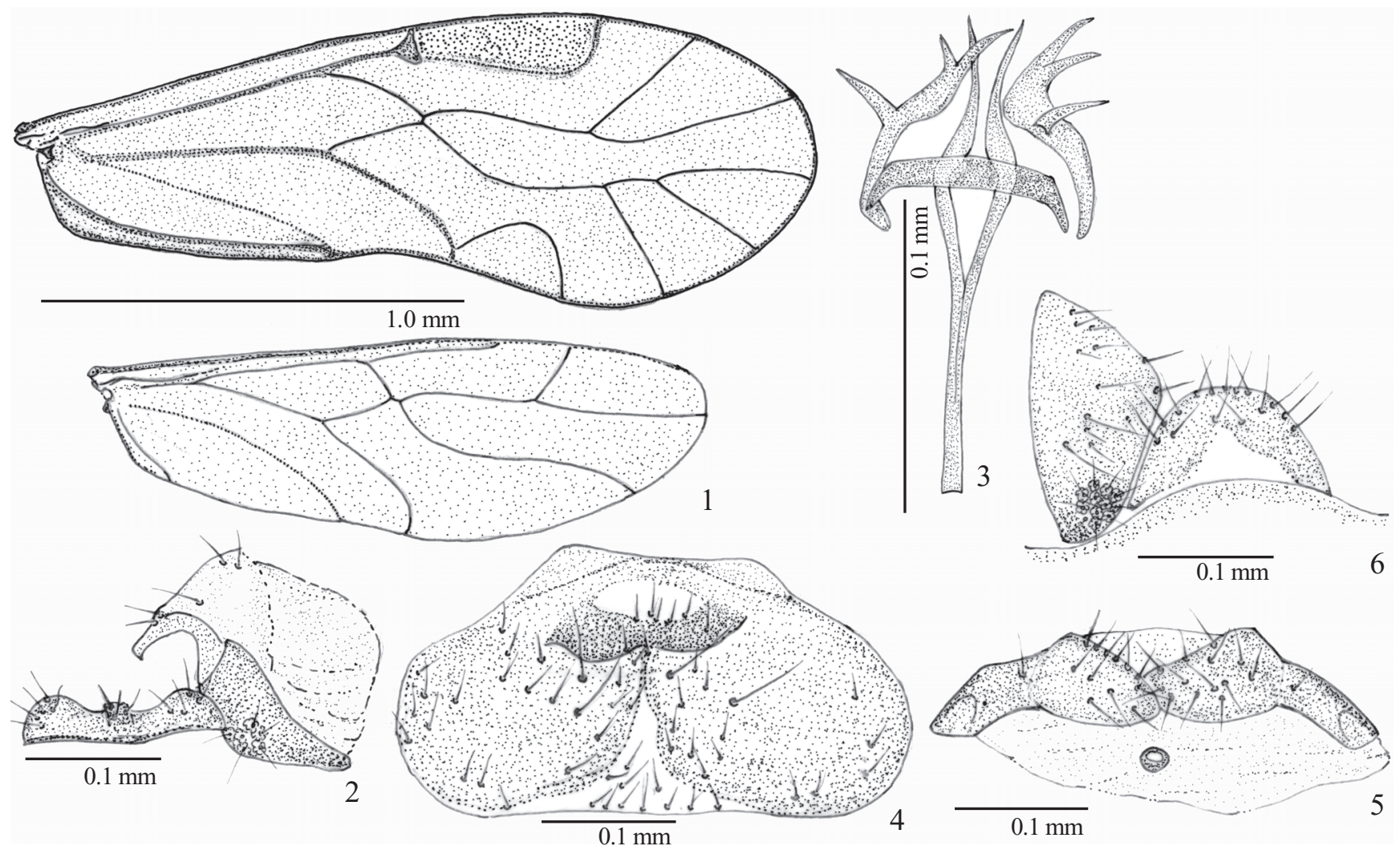

Figs. 1-6. Lachesilla cladoclaspers sp. nov. 1. Fore- and hind- wings, male. 2. Epiproct and left paraproct, male. 3. Phallosome, hypandrium and claspers, male. 4. Subgenital plate, female. 5. Gonapophyses and ninth sternum, female. 6. Right paraproct and epiproct, female.

Description. Male. Color (in $80 \%$ ethanol). Body chestnut brown. Compound eyes black, ocelli hyaline, with brown centripetal crescents. Maxillary palps dark brown, antennae brown, legs pale brown. Thoracic pleura with a slender ochre band above the level of the coxae. Forewings slightly opaque, with a dark orange hue. Abdomen creamy, with ochre, transverse subcuticular rings, less pigmented ventrally.

Morphology. Hypandrium wide transversely, narrow antero-posteriorly, with antero-lateral corners projected. Claspers curved, proximally narrow, wider in the middle, distally branched, each branch acuminate; a stout, mesal acuminate apophysis, directed outward. Phallosome apodemes long, slender, basally joined, distally dilated, narrowing to end, acuminate. Paraprocts broad, with setae as illustrated; with aquiline mesal prong; sensory fields in a deeply pigmented, sclerotized area, with eight trichobothria in basal rosettes. Epiproct wide, narrow, with postero-lateral corners rounded, bearing a setal field; posterior border concave, with a small, quadrate, setose projection in the middle.

Measurements (in $\mu \mathrm{m}$ ). FW: 1872, HW: 1436, F: 337, T: $673, \mathrm{t}_{1}: 231, \mathrm{t}_{2}: 83$, ctt 1 : 19, $\mathrm{f}_{1}: 216, \mathrm{f}_{2}: 182, \mathrm{f}_{3}: 160, \mathrm{f}_{4}: 134$, IO: 265, D: 148, d: 94, Mx4: 72, IO/d: 2.8, PO: 0.63 .

Female. Color. Same as the male.

Morphology. Forewing pterostigma almost rectangular, slightly wider posteriorly. Veins Rs-M joined by a short crossvein. Areola postica wide basad, apically rounded. Subgenital plate broad, almost straight posteriorly, with four mesal macrosetae, other setae as illustrated; with slightly prominent postero-lateral shoulders; a transverse, pigmented band mesally, near posterior border, an elliptic hyaline area next to posterior border of transverse pigmented band; pigmented area of the plate deeply cleft anteriorly in the middle. Gonapophyses broad, setose, mesally directed, with proximal halves narrow. Ninth sternum membranous, spermapore in the middle, with a narrow, pigmented rim. Paraprocts almost elliptic, setose, sensory fields with 11 trichobothria in basal rosettes and one marginal trichobothrium without basal rosette. Epiproct semicircular, with pigmented area anteriorly cleft in the middle; setal field on distal third.

Measurements (in $\mu \mathrm{m}$ ). FW: 1743, HW: 1331, F: 323, T: $647, \mathrm{t}_{1}: 227, \mathrm{t}_{2}: 80, \mathrm{ctt}_{1}: 19, \mathrm{f}_{1}: 173, \mathrm{f}_{2}: 147, \mathrm{f}_{3}: 135, \mathrm{f}_{4}: 106$, IO: 269, D: 152, d: 92, Mx4: 88, IO/d: 2.9, PO: 0.60 .

Etymology. The specific name refers to the branched male claspers.

Comments. Lachesilla cladoclaspers sp. nov. is the only species in its group with the claspers distally branched; the female can be separated from the other species in the group, by the straight posterior border, with slightly prominent corners, by the hyaline area between the mesal pigmented band and posterior border of the subgenital plate, and by the robust gonapophyses, proximally narrow. It constitutes the third species in group riegeli known in Brazil, the first of its group known in the state of Bahia, and the fifth of its group known in South America. 
Type material. Holotype male, BRAZIL. Bahia. Chapada Diamantina,

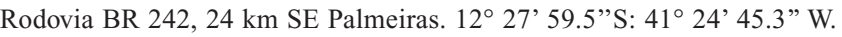
9.IX.2012. Beating shrub branches with dead leaves. A. N. García Aldrete \& A. M. da Silva Neto. Paratypes. Two females, Brazil. Bahia. Chapada

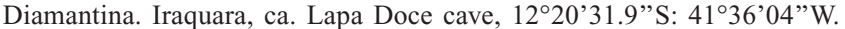
9.IX.2012. On dead palm bract, 1 female. Same collectors.

\section{Lachesilla nilopecanhensis sp. nov.}

(Figs. 7-10)

Diagnosis. Hypandrium narrow, transverse, almost rectangular, distal region of each clasper straight, with apex slightly hooked, directed outwards. Epiproct with small, sclerotized mesal process near posterior border.

Description. Male. Color (in $80 \%$ ethanol). Body pale brown. Compound eyes black, ocelli hyaline, without pigmented centripetal crescents. Maxillary palps and antennae brown, legs pale brown. Tergal lobes of meso- and metathorax slightly more pigmented than rest of the thorax. Abdomen creamy, with ochre, transverse subcuticular rings, less pigmented ventrally.

Morphology. Forewing pterostigma elongate, almost rectangular; veins Rs-M joined by a short crossvein, areola postica wide basad, apically rounded. Hypandrium almost rectangular, with setae as illustrated; claspers anteriorly rounded, with sides parallel, bearing two long setae mesally; distal regions of claspers straight, each with a small, pointed tip directed outward. Phallosome apodemes fused to form a baculum, divided distally, each side extended into a triangular lamella next to posterior border of hypandrium. Paraprocts almost elliptic, with setae as illustrated, with a less pigmented area on distal half; sensory fields with 11 trichobothria issuing from basal rosettes, and a marginal trichobothrium without basal rosette. Epiproct almost straight anteriorly, rounded posteriorly, with setal field as illustrated on distal third, and a small, strongly sclerotized triangular mesal process, next to posterior border of epiproct.

Measurements (in $\mu \mathrm{m})$. FW: 1660, HW: 1263, F: 320, T: $575, \mathrm{t}_{1}: 212, \mathrm{t}_{2}: 90, \mathrm{ctt}_{1}: 15, \mathrm{f}_{1}: 238, \mathrm{f}_{2}: 228, \mathrm{f}_{3}: 194, \mathrm{f}_{4}: 163$, IO: 237, D: 161, d: 111, Mx4: 82, IO/d: 2.13, PO: 0.68 .

Etymology. The specific name refers to the type locality: Nilo Peçanha.

Comments. Lachesilla nilopecanhensis sp. nov. is close to Lachesilla trunca García Aldrete, 2000, from Brazil (Pará, Pernambuco), and Panama. It differs from L. trunca in that the hypandrium is broader, not as narrow transversely, the

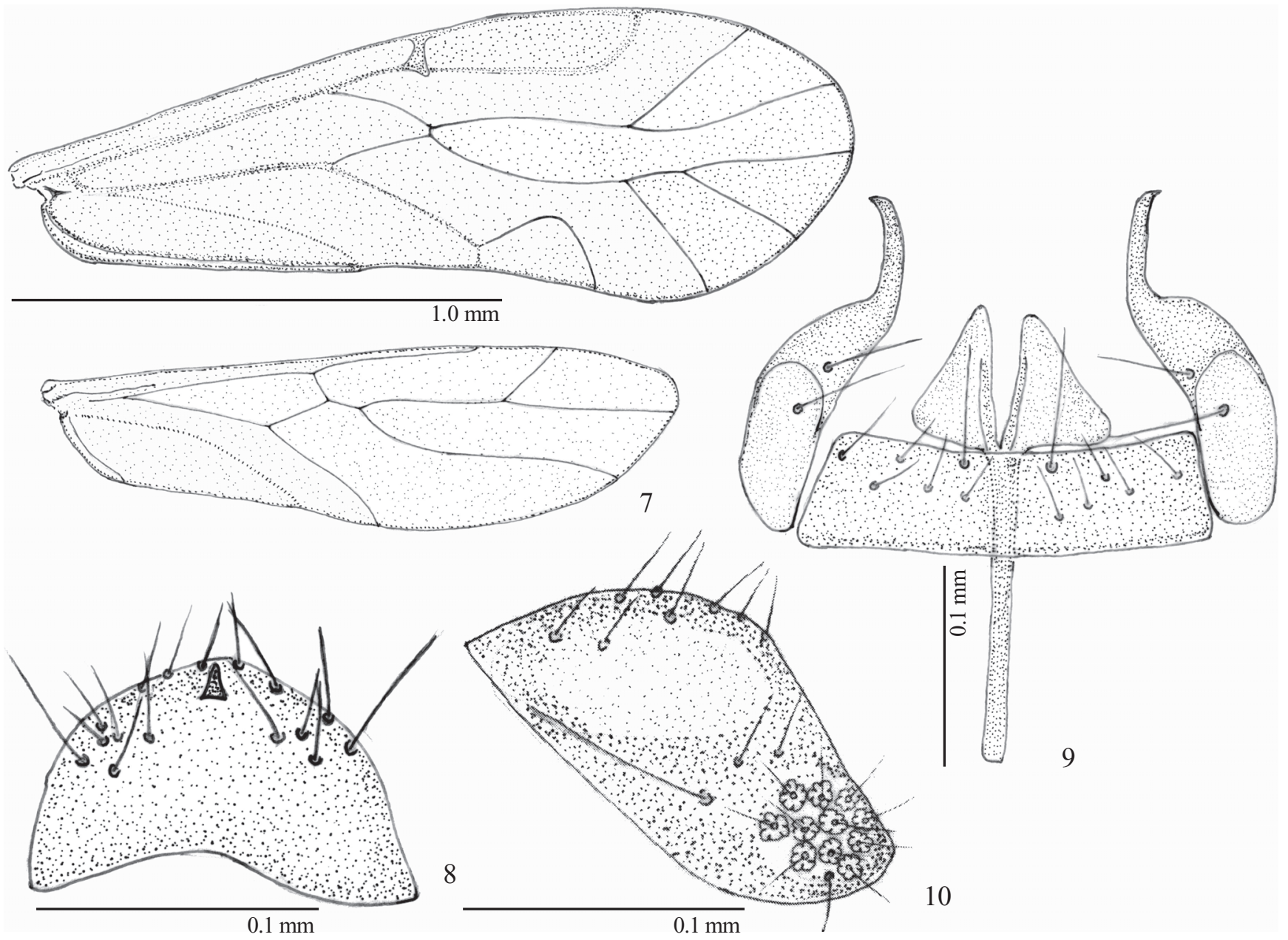

Figs. 7-10. Lachesilla nilopecanhensis sp. nov. Male. 7. Fore- and hind- wings. 8. Epiproct. 9. Phallosome apodeme, hypandrium and claspers. 10. Right paraproct. 
apices of the claspers are projected to the sides, veins Rs-M are joined by a crossvein, not diverging from a point as in $L$. trunca, and the epiproctal process is more slender in $L$. nilopecanhensis. It is the $20^{\text {th }}$ species of its group recorded in Brazil, and the third species of its group recorded in the state of Bahia.

Type material. Holotype male, BRAZIL. Bahia. Nilo Peçanha. 8.I.2011. Malaise trap. A. Calor

\section{ACKNOWLEDGMENTS}

ANGA thanks Instituto de Biología, Universidad Nacional Autónoma de México for continuous research support. AMSN thanks Freddy Bravo, Coordinator of the Invertebrate Area for the project PPBio-Semiarid (Grant 558317/ 2009-0) at the Universidade Estadual de Feira de Santana,
Bahia, Brazil, for his support, and for a research grant to conduct a survey of the Psocoptera in northeastern Brazil.

\section{REFERENCES}

García Aldrete, A.N. 1974. A classification above species level of the genus Lachesilla Westwood (Psocoptera: Lachesillidae). Folia Entomológica Mexicana 27: 1-88.

García Aldrete, A.N. 1982. The species group Riegeli of the genus Lachesilla (Psocoptera: Lachesillidae) Diagnoses, records and descriptions of new species. Zoologischer Anzeiger 209: 196-210.

García Aldrete, A.N. 1997. New South American Lachesilla (Psocoptera: Lachesillidae). Revista de Biologia Tropical 44: 209-223.

García Aldrete, A.N. 2000. New South American Lachesilla in the Group Forcepeta (Psocoptera: Lachesillidae). Acta Zoológica Mexicana 80: 69-99.

García Aldrete, A.N. \& Mockford, E.L. 2009. A list of Psocoptera (Insecta: Psocodea) from Brazil. Revista Mexicana de Biodiversidad 80: 665-673.

Mockford, E.L. 1993. North American Psocoptera (Insecta). Flora and Fauna Handbook 10. Gainesville, Sandhill Crane Press, 455 p. 